\author{
Dariusz Kuncewicz ${ }^{1}$ \\ University of Social Sciences and Humanities \\ Kinga Lachowicz-Tabaczek ${ }^{2}$ \\ University of Wroclaw \\ Jacek Załuski ${ }^{3}$ \\ Kozminski University
}

\title{
Why insight in psychotherapy does not always lead to behaviour change?
}

\begin{abstract}
:
The purpose of this review was to come closer to answering the question why insight gained in psychotherapy does not necessarily lead to a change in patient's behaviour. The review of literature on the subject of insight allowed us to distinguish two types of insight: "more intellectual than emotional" $(I-e)$ and "more emotional than intellectual" (E-i). In addition, we differentiated $E-i$ insight with a component of negative emotions (aversive) and with a component of positive emotions (corrective). We assumed that each type of insight would motivate the patient to change their behaviour in a different way. The $I-e$ insight makes it easier for the patient to achieve concrete adaptive goals, the $E-i$ aversive insight discourages them from attaining maladaptive goals, while the $E$-i corrective insight encourages them to form and follow adaptive goals. We also analysed the influence on behaviour change of some other factors, co-occurring with insight: the therapeutic relationship, the actions of the patient and his narrative motivation. Insight does not always lead to a change in behaviour because: 1) the type of the insight does not match the type of patient's motivation; 2) insight occurs in the context of a weak therapeutic relationship or is not reinforced by the patient's actions; 3 ) insight is not a key factor of change, but rather its effect or indicator.
\end{abstract}

\section{Keywords:}

insight, behaviour change, goal-oriented motivation, impulsive motivation, narrative motivation

1 Dariusz Kuncewicz, Department of Clinical Psychology, Faculty of Psychology, University of Social Sciences and Humanities, ul. Chodakowska 19/31,03-815 Warszawa; dkuncewicz@swps.edu.pl.

2 Kinga Lachowicz-Tabaczek, Department of Psychology, Faculty of Pedagogical and Historical Sciences, University of Wroclaw, ul. Dawida 1, 50-527 Wroclaw; k.lachowicz-tabaczek@psychologia.uni.wroc.pl.

3 Jacek Załuski, Management Division, Kozminski University, 03-301 Warszawa, ul. Jagiellońska 57/59; jzaluski@kozminski.edu.pl. 


\section{Streszczenie:}

Celem opracowania było zbliżenie się do odpowiedzi na pytanie, dlaczego wgląd uzyskiwany podczas psychoterapii nie zawsze prowadzi do zmiany zachowania pacjenta. Eksploracja literatury na temat wglądu w psychoterapii pozwoliła wyodrębnić wgląd „raczej intelektualny, niż emocjonalny” (I-e) oraz „raczej emocjonalny, niż intelektualny” (E-i). Dodatkowo wyróżniliśmy wgląd E-i z komponentą emocji negatywnych (awersyjny) oraz z komponentą emocji pozytywnych (korektywny). Uzasadniliśmy, że każdy rodzaj wglądu w inny sposób motywuje pacjenta do zmiany zachowania. Wgląd I-e ułatwia pacjentowi realizację wyraźnych celów adaptacyjnych, wgląd E-i awersyjny zniechęca do realizacji celów nieadaptacyjnych, natomiast wgląd E-i korektywny zachęca do przyjęcia i realizacji celów adaptacyjnych. Poddaliśmy też analizie wpływ niektórych, współwystępujących z wglądem, uwarunkowań zmiany zachowania: relacji terapeutycznej, działań pacjenta oraz jego motywacji narracyjnej. Wgląd nie zawsze prowadzi do zmiany zachowania dlatego, że: 1) typ wglądu jest niedostosowany do typu motywacji pacjenta, 2) wgląd pojawia się w kontekście zbyt słabej relacji terapeutycznej lub nie jest wzmocniony działaniem pacjenta, 3) wgląd nie jest kluczowym czynnikiem zmiany, tylko jej efektem bądź wskaźnikiem.

\section{Słowa kluczowe:}

wgląd, zmiana zachowania, motywacja celowa i impulsywna, motywacja narracyjna

A thirty-year-old man started to show signs of panic disorder after breaking up with his partner. This man has already been in therapy several times, and thanks to that he understood that he tended to react with anxiety to any separation in his life. He was also aware of the source of his anxiety, which was a separation from his mother, who was hospitalised for many months when he was barely four years old. Even though in the course of his therapy he achieved many more insights into the nature and source of his anxiety, he did not eliminate it. Another patient, a high-earning financial analyst, understood through his therapy that his depressive reactions are associated with his non-autonomous choice of career path. In therapy he realised that he chose his career in order to please his critical and demanding father, which required him to abandon his artistic passions. When he realised how much he has lost in his life, his depressive reactions intensified - he began to blame himself for not standing up to his father and not following his own path.

Both of the above examples (see Friedman, 2011) seem to reflect a phenomenon occurring in psychotherapeutic practice. Some clients, even though they understand more and more of their life, do not introduce positive changes into it, or even experience some negative ones. Why? In order to come closer to answering this question we should first clarify what type of concrete benefits, if any, the patient can gain from insight, as well as what such a process might consist in.

Insight has long been deemed to be one of the key therapeutic factors by therapists from various orientations (Mahoney, Norcross, Prochaska, \& Missar, 1989). Nonetheless, in the last sixty years there were just a dozen or so studies carried out which explored its relationship with change in psychotherapy. Relationships between insight in 
psychodynamic psychotherapy and improvements in the patients' functioning were found in six of the eleven studies (research reviews: Gibbons, Crits-Christoph, Barber, \& Schamberger, 2007; Johansson et al., 2010). In the context of cognitive-behavioural therapy this association was found in three out of four studies, whereas in another study, exploring the effectiveness of marriage therapy, it was not found at all (research review: Grosse Holtforth et al., 2007).

The research evidence so far provides initial support for the hypothesis that insight may lead to therapeutic results. Nevertheless, the clear ambiguity of the obtained results makes it difficult to formulate generalised conclusions. This ambiguity may stem from differences in, for example, the adopted definition of insight, specification of its key aspects, methods of measuring insight, the type of disorders, the choice of the indices of effectiveness of therapy, or the importance attributed to insight across different therapeutic modalities (see: Connolly Gibbons et al., 2007, Hill et al., 2007).

\section{The concept of insight}

With regard to the differences in the understanding of insight it is worth noting that in psychodynamic therapy the patients are encouraged to discover the inner conflicts and their associations with interpersonal relationships, while in the cognitive-behavioural therapy they are encouraged to discover new cognitive schemas and new meanings of interpersonal situations (Elliott et al., 1994). In experiential therapy insight most often relates to the increasing self-awareness and understanding of one's feelings, and in the systemic therapy - to the discovery of cycles of reciprocal reactions within relationships and to understanding "how" (not "why") they become problematic (Rubinstein-Nabarro, 1996). The differences in the definition of insight within different therapeutic orientations also imply markedly different methods of its measurement. For example, the PCCS scale (Patient Cognitive Change Scale), used in a study of patients taking part in cognitive-behavioural therapy, includes such aspects of insight as, for example, "becoming aware of one's beliefs" or "identification of errors in thinking" (Tang \& DeRubens, 1999). In turn, the measurement of the "psychodynamic" insight with the use of the IS (Insight Scale) is based on the estimate of, for example, the patient's understanding of his "internal conflicts, associated problems, reoccurring behaviours and associations with previous experiences" (Johansson et al., 2010).

Because of the diversity of definitions and measurement methods a group of twenty eight researchers and practitioners (Hill et al. 2007), all of whom were co-authors of the book "Insight in Psychotherapy" (Ed. L.G. Castonguay \& C. Hill), attempted to coin a common definition of this term. The majority of them agreed that insight is usually 
conscious in character and is associated with both the feeling of novelty (that is, with the client understanding something in a new way), and the formation of new connections (that is, with discovery of new relationships between past and present events, the therapist, the significant persons, cognition, emotions or contradicting statements). Eventually, the majority of authors agreed that insight can be defined as a "conscious meaning shift involving new connections (i.e. 'this relates to that' or some sense of causality)" (Hill et al., 2007, p. 442). This definition was adopted as a starting point in our further analyses.

\section{The concept of behaviour change}

In psychoanalytical tradition, which attributes a considerable therapeutic potential to insight, behaviour change was for a long time seen as a natural consequence or even an integral part of a "true" insight (Sandler, Dare, \& Holder, 1973). This way of thinking is currently difficult to uphold, as an observable therapeutic change often occurs only after some time after achieving insight (see Høgland et al., 1994). In such cases it is unclear to what extent the change was brought about by insight alone, and to what extent by other, mediating factors, initiated by the insight or co-occurring with it. Another extreme is the reduction of the change influenced by insight to a change of a first and foremost "internal" character, for example within the area of thought and experiencing. In this case, potential consequences of insight may be confused with its indicators. Therefore, according to Gelso and Harbin (2007), a valid examination of therapeutic consequences of insight requires the separation of the concepts of change and insight. The authors proposed that change influenced by insight should be described in its most visible, "external" manifestations, that is, in the actions or in another observable way of functioning of the patient. For instance, the process of the lowering of the level of anxiety can be analysed on the cognitive, emotional, verbal and motor levels (see: Wachtel, 1997). However, only the latter two levels are observable and can be differentiated from the cognitive and emotional aspects of insight. In our further discussion we will, following Gelso and Harbin (2007), use the term behaviour change in relation to verbal and motor reactions, as an "external" (manifested through widely understood action) expression of the changes of a more "internal" character.

In the context of the above definition, an adequate indicator of behaviour change would be, for example, a reduction in psychopathological symptoms or a change in interpersonal functioning (see: Johansson et al., 2010). Consequently, the inadequate indicators of behaviour change would include a sense of change, experience of positive emotions or of change in cognitive schemas (see: Grosse Holthfort, et al., 2007). 


\section{Insight and motivation to change behaviour}

Assuming that all behaviours are motivated (Franken, 2002), we can infer that the behaviour change is dependent on either conscious or unconscious motivation of the person to modify their behaviour. Further, we can assume that the stronger the motivation to change behaviour brought about by insight, the greater the probability of the change actually occurring. Therefore, does insight, understood as a conscious change of meanings, accompanied by formation of new connections, actually induce motivation to change behaviour?

In order to better estimate the motivational potential of insight, we will examine more closely the mechanisms underlying the "conscious change of meanings" as well as the "new connections" that might be related to this change. We will base our discussion mostly on two contemporary conceptualisations of insight: psychodynamic and cognitive-behavioural.

\section{Psychodynamic and cognitive-behavioural conceptualisations of insight}

In psychodynamic perspective, the "conscious change of meanings" consists in becoming aware of or understanding the "connections" between one's feelings, thoughts and actions or between the internal processes (thinking, experiencing) and the past and present events (Gelso \& Harbin, 2007). However, just the intellectual understanding, or the so called intellectual insight - which is emphasised also by researchers from other orientations than psychodynamic (for research review see: Elliott et al., 1994) - is not sufficient to bring about a change in behaviour. This change occurs mostly due to emotional insight, that is, understanding accompanied by emotional experiencing. Intellectual insight plays an important role of an "initial map" of the problematic areas and their reciprocal connections, which prepares the person for the experience of emotional insight. The patient first identifies his conflicts internally, connects them to a series of experiences from his childhood, and even comes to understand their destructive influence on his present relationships, feeling that "there is something to that". In time he begins to experience emotions of which he was not previously aware in parallel with the continuing analysis of associated intellectual material. For example, he might realise how his strong feelings of worthlessness are associated with his early, difficult relations with caregivers, and how much he wanted and still wants to live differently. Gelso and Harbin (2007) believe that it is this kind of internal change (the conscious change of meanings) which brings a series of benefits to the patient: a) it increases his ability to differentiate the pain situated in his past relationships and his present experiences; b) it limits generalisations of 
maladaptive, fixed in the past reactions to present situations, and c) it increases motivation to abandon the maladaptive actions and initiate new, more constructive ones.

In the cognitive-behavioural perspective, the "conscious change of meanings" indicates gaining new understanding of self or others (e.g. of the causes, limitations or consequences of behaviours, thoughts, intentions and feelings of oneself or of other people). The patient understands himself or others in a new way when she becomes aware of the "connections" between mental representations which she previously did not perceive to be connected with one another or associated in other ways (Grosse Holtforth et al., 2007). This new understanding of self and others is, to a larger degree than in the psychodynamic approach, intellectual rather than emotional in character. Intellectual insight functions not as much as a "map", preparing the person for the change influenced by emotions, as it is seen as a potential for change in itself. This potential stems from the cognitive therapy's greater emphasis on the search for "connections" based on logical thinking (e.g. discovering errors in thinking about a relationship with a loved one). In psychodynamic therapy the search for "connections" (e.g. discovering similarities in one's attitude to the therapist and to the loved one) is based to a greater extent on associative thinking (see, e.g. Gabbard, 2010). A patient working with a cognitive-behavioural therapist may, for example, become aware that her maladaptive attitudes did in fact make sense in her earlier life and that many people in such circumstances as the ones she was in would react to rejection in a similar way to her - but also that at present such reactions are not justified. Conclusions drawn from past experiences (for example, "people cannot be trusted"), even though they seemed true in the past, are no longer true. They cannot be generalised onto present relationships, since there are people in the patient's surroundings, including the therapist, who care about her and value her just as she is. Grosse Holtforth and colleagues (2007) believe that this type of conscious change of meanings (they call it clarification of meanings): a) increases the sense of efficacy and control in life; b) facilitates the experience of freedom from past and present limitations in functioning; c) expands the repertoire of behaviours towards self and others.

In summary, even though the potential effects of insight in psychodynamic and in cognitive behavioural therapies turned out to be comparable (on the level of the reduction in psychopathological symptoms, see Ablon \& Jones, 1999; Jones \& Pulos, 1993), they may rely on separate mechanisms of insight. This hypothesis is supported by a comparison by Eliott and colleagues (1994), who analysed the experiences of insight of three persons participating in psychodynamic-interpersonal therapy and three persons taking part in cognitive-behavioural therapy (the insight was estimated according to the following criteria: metaphorical imagery, perception of patterns and connections, suddenness, and novelty). Insights gained by patients in cognitive-behavioural therapy did not include 
- contrary to insights in psychodynamic therapy - an awareness of emotional pain. What is more, the "cognitive-behavioural" experiences of insight were mostly related to reattributions, while the "psychodynamic" ones - to the discovery of connections between key conflicting interpersonal themes, emerging during subsequent sessions.

Also, results obtained by Jones and Pulos (1993) seem to correspond to the above conclusions, as they indicate the prevalence of processes of either rather intellectual, or rather emotional character, depending on the type of therapy. The researchers, using a 100-item tool describing processes occurring in therapy (Psychotherapy Process Q-set), compared the recordings of sessions of 30 patients undergoing brief psychodynamic therapy and 32 patients participating in cognitive-behavioural therapy. The results have shown that - regardless of many common elements - there were significant differences in the process of therapy depending on its type. Cognitive-behavioural therapy facilitated the development of control over negative emotions through the use of intellect and rational thinking by the patients, in the context of conscientious encouraging, supporting and comforting by the therapist. On the other hand, in psychodynamic therapy the emphasis was laid on evoking emotions, becoming aware of problematic feelings as well as integration of present difficulties with past experiences, using the therapeutic relationship as a factor of change.

The specific character of "psychodynamic" insight, as compared to "cognitive-behavioural" one, is also indicated in the research by Connolly Gibson and colleagues (2009) as well as by Kallestad and colleagues (2010). One of the common elements of both studies was the use of insight measurement tools based to a larger or lesser degree on psychodynamic conceptualisation of insight. Even though in both studies the improvement in symptoms occurred in patients in both psychodynamic and cognitive-behavioural treatment, the association between the achievement of insight and the reduction in symptoms was present only for patients in psychodynamic treatment.

\section{Type of insight and motivation to change behaviour}

The outlined conceptualizations of "psychodynamic" and "cognitive-behavioural" insight, as well as the currently still limited number of obtained results which indicate differences in the process of insight in different types of therapy, suggest that it is possible to initially distinguish two types of insight: 1) $E$ - $i$ insight, with a larger component of emotional (or associative) processes than intellectual processes; 2) I-e insight, with a larger component of intellectual (or causal) processes than emotional ones.

Specifying this distinction further, we can assume that the distinctive characteristic of availability of emotions in both cases regards not only their intensity, but also their 
valence. The $E-i$ insight is more often accompanied by mental pain and negative emotions (see Eliott et al., 1994). On the other hand, the I-e insight is more typically associated with emotions such as joy, which is related to the process of learning (Grosse Holforth et al., 2007). It is worth noting that the feeling of joy accompanying insight may result from both positive reinforcement (insight into new, concrete possibilities gives hope of solving one's problems) (see Grosse Holforth et al., 2007) as well as negative reinforcement (insight into emotional nature of one's problem, evoking a desire for change and hope for a positive breakthrough in life). Still, it can be assumed that joy derived from positive reinforcement (stronger?) is more characteristic of insight of the I-e type, while joy coming from negative reinforcement (weaker?) is more typical of the $E-i$ type insight.

Further, we can presume that the two types of insight differ with regard to the material subjected to the conscious, intellectual analysis. The I-e type of insight concerns the connections between elements which were already present in one's awareness, while the $E-i$ insight is associated with the connections between the material one is already aware of and that which has not yet reached awareness (see: Grosse Holforth et al., 2007). In the language of the dual process theory, that is, of the reflexive-impulsive processing (Smith \& DeCoster, 2000; Strack \& Deutsch, 2004; see Bargh, 1997; Epstein, 1990), we can say that reflexive processing (based on declarative memory) in case of the $E-i$ insight, includes more of the material typical to the impulsive system (contained in associative memory) than in the case of the I-e type insight.

The last of the aforementioned differences is very important for the understanding of the motivational mechanisms in both types of insight - that is because the reflexive and the impulsive systems use different types of motivations. Motivation in the reflexive system is goal-oriented. It relies on a conscious, intentional pursuit of goals, which are based on particular values and representations of future, desirable states. On the other hand, motivation typical for the impulsive system is affective in character and is based on pre-conscious or unconscious approaching or avoiding (Strack \& Deutsch, 2004). It is not difficult to imagine a situation in which a patient consciously strives for a beneficial change (e.g. wants to become more independent), while simultaneously subconsciously sabotaging his endeavours (e.g. by seeking safe dependence) (see Greenwald, 1973; Yalom, 1980).

In somewhat simplistic terms, we can say that if the goal-oriented motivation is a key part of an insight, then most probably the $I-e$ insight will be sufficient to initiate action towards change. For example, the patient can, through the I-e type of insight, come to an understanding of how his beliefs up till now had limited his ability to solve his problem. He may also understand what other beliefs might be better adjusted to his 
present situation and what new capabilities he now has which can help him cope with his problem. Because the conscious motivation for change does not seem to be undermined by the competing impulsive-affective motivation, the patient can participate in therapy with a view to coming to understand his problem and learning new strategies of coping with it, rather than in order to, for example, prove to the therapist that he is incompetent and prove to himself that he is "worthless". In such case the patient actually (not just in pretense) cooperates with the therapist and gains new competencies, which increases his sense of self-efficacy and further motivates him to introduce desired changes (see Grosse Holforth et al., 2007). In general, the benefits of the $I-e$ insight stem from the expansion of resources necessary to achieve the desired, relatively unambiguous goals.

However, if for the given patient the impulsive-affective motivation is more important, then she will most probably benefit more from the $E$ - $i$ type insight. Through the $E-i$ type insight the patient may become aware of the highly frustrating fact that she is directed by, for example, aggressive or symbiotic motivations, which do not agree with her image of herself. What is more, she can notice the connections between these motivations and the often painful experiences from her past, as well as with problems in her present relationships - including the relationship with her therapist. Taking into account the fact that reflexive processing exhausts the resources of attention and working memory faster than associative thinking (see, e.g. Barrett, Tugade, \& Engle, 2004), the E- $i$ type of insight would probably be facilitated by minimisation of logical analysis in order to enhance the systematic exploration of associative connections. If the parts of material which act against change, and which are often associated with impulsive-affective motivation, are introduced into the field of attention and kept in the working memory for a prolonged time, the patient will have a chance to process them reflexively and thus subject them to her conscious control. She can then make a decision to abandon the pursuit of goals which prevent the desired change (see Greenwald, 1973; Yalom, 1980), or to reformulate them to agree with the goals she wants to achieve during therapy. In summary, the benefits of the $E-i$ type insight stem from clarification or disambiguation of the desired goals.

In case of patients showing relatively unambiguous motivation for change (goaloriented motivation relatively integrated with impulsive-affective motivation), work directed at achieving the $E$ - $i$ type insight seems inadequate and too costly emotionally. Such patients usually cooperate well with the therapist, quickly learn new skills with regard to analysis and control of their own states and are efficient in introducing them into their lives (see the so called "clients"; DeShazer, 1985). Because of that they do not need insight as an aid for their motivation for change. On the other hand, in case of patients with clearly ambiguous motivation for change (goal-oriented motivation in opposition to the 
impulsive-affective motivation), work directed at achieving the I-e type insight may be ineffective. Such patients appear to be doing everything they can to prevent success in therapy (see the so called "especially difficult clients"; Kottler, 1992). Thus, insight which expands awareness of the "tools" that can be used to solve problems will most probably not motivate them to make use of those tools.

\section{Factors co-occurring with insight and behaviour change}

As we have shown earlier insight, regardless of its type, may motivate behaviour change. Not detracting from the importance of insight in psychotherapy, we must however point out several other factors, without which the type of insight that motivates the patient to change may not occur at all or may not be potent enough. Moreover, we would like to suggest that insight can be just one part of a more complex process of therapeutic change and may not always be its necessary part.

\section{Insight and the therapeutic relationship}

One of the most important moderators of the relationship between insight and behaviour change may be the therapeutic relationship (Gelso \& Harbin, 2007; Hill et al., 2007). A good therapeutic relationship provides the patient with support needed for insight work and for behaviour modification. Gelso and Harbin (2007) assume that existence of such a therapeutic relationship is indicated by: mutual trust, emotional bond and cooperation between the patient and the therapist. When the patient trusts the therapist (and her intentions and skills) more than he is afraid of his therapist, it is much easier for him to allow himself to "observe" his threatening experiences and thoughts (see the buffering effect of therapeutic relationship in this study: Gelso, Hill, Mohr, Rochlen, \& Zack, 1999), as well as to risk a change of his previous patterns of functioning. The therapeutic relationship should therefore facilitate: a) the achievement of the $E-i$ type insight into the emotional nature of problems, as well as the $E$ - $i$ type insight into dysfunctional thinking schemas and new solutions; b) initiation of attempts to change behaviour, which are motivated by the $E-i$ type insight or discovered through the I-e type insight.

The role of the therapeutic relationship in the process of making changes in the patient's life is not limited just to providing safe environment, which encourages self-exploration and testing of new behaviours. The therapeutic relationship in itself presents an attractive subject for insight. Assuming that it consists of three components (that is, therapeutic alliance, transference and the real relationship; Gelso \& Harbin, 2007), it can constitute a basis for exploration of both the relational patterns revealed through transference 
(and countertransference) and of the processes occurring within the developing real relationship between the patient and the therapist (Yalom, 1980).

Insight into transference reactions allows the recognition of distortions in perception of the relationship with the therapist and of analogous distortions in perception of relationships with one's loved ones. Becoming aware of maladaptive patterns from the past which are repeated in present relationships increases the patient's readiness to abandon them (see Kuncewicz, 2009) and to try out new patterns instead (Gelso \& Harbin, 2007). On the other hand, insight into the real relationship with the therapist relates more to the patient's knowledge of how she experiences and understands her therapist as a person as well as how each of them experiences the other. If the therapist takes care to make the relationship authentic and adequate (without distortions from countertransference), the experiences of the patient in such relationship are mostly positive, associated with liking and mutual care (see Gelso, 2002). According to Gelso and Harbin (2007), this type of understanding can be successfully generalised onto other close relationships outside of therapy. For instance, a patient who discovers that the therapist likes him as a person may also discover that he is liked by some other people close to him. A patient who had courage to trust the therapist as a person a bit more, and experienced the positive consequences of this decision, may come to understand that it is this taking of risk to trust others despite fear of rejection that forms the basis of close relationships (see: model of risk regulation in close relationships: Murray, Holmes \& Collins, 2006).

Transference insights, as well as the real aspects of the relationship with the therapist, are highly emotional in character; thus, to all appearances they resemble the $E-i$ type insight. However, each of them seems to play a different role in the therapeutic process. Insight into transference aspects of the relationship functions more as a negative reinforcement (the patient realises which patterns she would rather not repeat in her relationships) - and thus it corresponds closely to the $E$ - $i$ insight, described earlier in this work. On the other hand, insight into real aspects of the relationship with the therapist acts more as a corrective experience, which increases hope (Hartman \& Zimberoff, 2004). Such experience is a strong positive reinforcement (the patient discovers which relationship patterns she would like to repeat). With regard to its association with positive emotions as well as being an opportunity for discovery of new possibilities, insight into the real relationship with the therapist is similar to the description of the $I-e$ type insight, although with regard to emotional intensity it more closely resembles the $E-i$ insight. Thus, insight into the real aspects of the relationship with the therapist combines beneficial aspects of both types of insight: the depth of emotional processing ( $E$ - $i$ insight) and learning new solutions (I-e insight). It provides the patient with an opportunity to modify the ways of reacting rooted in the affective-impulsive system on the spot, 
within the session and within the safe relationship with the therapist. Possibly for this reason Gelso and Harbin (2007), as well as Yalom (1980), believe that work on insight into the real relationship between the patient and the therapist carries the greatest potential for constructive change.

The therapeutic relationship may also constitute a stand-alone change factor, independent from insight (see the results of a metaanalysis by Grencavage \& Norcross, 1990). This is because the changes influenced by corrective experiences within a relationship with an emotionally engaged, supportive therapist occur also on the level of procedural memory. The patient acquires in this way new implicit knowledge (without a symbolic representation) regarding appropriate ways of behaving, feeling and thinking in contexts of different relationships (Gabbard, 2010; Lyons-Ruth, 1998). Thanks to this knowledge he unintentionally "restructures" his previous relational schemas, and in parallel with this restructuring he also modifies his behaviour (Amini et al., 1996).

\section{Insight as a consequence of behavior change}

Our analysis so far regarded the mechanisms of behaviour change due to insight. However, a reverse process is also possible, that is, insight may be brought about by a change in behaviour. This effect has been repeatedly observed by behavioural therapists (see Cautela, 1993; Powell, 1986, 1996). For instance, in a university clinic run by Powell (1986), the "unplanned" insight turned out to be an important factor of therapeutic change for as many as $15 \%$ of patients participating in behavioural therapy due to, for example, migraines, symptoms of Raynaud's disease or fear of public appearances. Case analyses have shown that insights achieved during behavioural therapy regarded the understanding of the relationship between the symptoms and their causes or consequences (Cautella, 1993), as well as of the associations between symptoms and emotions or events that were previously unconscious (Powell, 1996). With regard to their content, these insights can be included in both groups - I-e or E-i. Taking into account the "randomness" of the insights it is more difficult to estimate their motivational function. The $I-e$ insight could have, for example, expanded the understanding of the causes and ways of coping with anxiety, which might have encouraged the patients to introduce more effective control in intrapsychic and interpersonal threatening situations. On the other hand, the $E-i$ insight could have, for example in the case of psychosomatic symptoms, increased awareness of emotional experiences associated with them as well as provided an opportunity for verbal expression and increased the patients chances of reflexive processing (see Niederhoffer \& Pennebaker, 2002; see Cozolino, 2002). It is likely that the combined process of expression and reflexive processing of emotions increases the effectiveness of internal mechanisms of emotion regulation (see Rottenberg \& Gross, 2007), and 
thus lowers the chronic emotional tension - subsequently reducing somatisation. Therefore, a behaviour change (reduction of symptoms) in the context of the $E-i$ type insight can also be explained in the "non-motivational" categories.

Hill and O'Brien (1999), as well as Gelso and Habrin (2007), suggest that the relationship between insight and behaviour change is more synergic, rather than automatic, in character (see Wachtel, 1997). This means that the benefits from an insight-oriented therapy may be greater when the therapist also focuses on the work on behaviour modification, which directly stems from insight. What is more, insight detached from action may turn out to be temporary, and therefore of limited usefulness. Action in some sense "expands" insight, broadening it to include additional modalities (e.g. motor-verbal), thanks to which insight can take a form of a more stable mental schema and be better integrated with the patient's concept of self (see ibid.).

\section{Insight and the narrative motivation}

What if insight "in and of itself" does not fulfill a motivational function? We will attempt to answer this question in the context of the narrative approach. This approach seems especially useful for our analyses due to its compatibility with contemporary models of memory (especially the connective, schematic and thematic models; for review see Niedźwieńska, 2004), neural network models (e.g. Cozolino, 2002), as well as with the "natural" language of psychotherapy (Frank \& Frank, 1993). From the narrative perspective, according to which an individual interprets events and experiences as particular stories (see: e.g. Bruner, 1986), insight can be seen as a mediating factor in the more fundamental process of therapeutic change. This fundamental therapeutic process is the construction of a story about oneself (autonarration), which structures experiences in areas of life important for the individual (Harber \& Pennebaker, 1992; McLeod, 1997).

From the teleological perspective of Trzebiński (2002) the autonarrative schemas are constructed around key themes, goals, values or intentions of the person (What do I want? What is important to me? What do I fear?). Complete autonarrative schemas consist of four sub-schemas: 1) intentions (aims, goals) important to the person; 2) other persons - partners of the subject; 3 ) possible complications, which befall the subject and her partners on the way to realise the intention; 4) conditions and methods of overcoming the complications and realising the intention (Trzebiński, 2002). The key motivational mechanism stems from the attempt to construct a coherent, complete and meaningful story about oneself in the context of experienced events. If autonarration in one of the important areas of life is not constructed, the motivation to create it is sustained and interferes with other autonarrations. This phenomenon resembles the Zeigarnik effect (1927/1983), which indicates a better memory (greater cognitive availability) of unfinished tasks as compared to 
finished ones, as well as the fact that the motivation to finish the unfinished tasks is sustained on the unconscious level and interferes with execution of current tasks. The presence of the motivation to "finish" or to create a complete and coherent story in narrative therapy is indicated by the so called "fragmented stories" (see Angus \& Bouffard, 2004), and in the experiential therapy - the so called "unfinished business" (see Greenberg, 2002). Let us imagine an adult patient who behaves in a childish way in an attempt to force his partner to give him the care he did not receive from his parents in childhood. It is possible that the expectations of care (intentions of the subject), due to a difficult childhood relationship with his parents (complications involving the partners of the subject) have not been fulfilled (the conditions for realisation of intention have not been met). The inability to organise one's experiences regarding the receiving of care into a coherent, satisfactory narration may act to sustain the motivation to receive care in the state of hyperactivity, making it difficult to engage more deeply in an equal relationship with one's partner.

Incoherence or fragmentation of autonarrative schemas may also depend on the degree of crystallisation of their fundamental sub-schemas, that is, intentions (see: Trzebiński, 2002). The more crystallised - that is, developed in the cognitive and affective aspects the "intention", the more it takes on the character of goal-oriented motivation (conscious and controlled) and the less of the impulsive-affective motivation (unconscious and automated).

In the former case, when the intention is well crystallised, the incoherence of autonarration regards rather its schematic level. The individual components (subschemas) of the autonarration are not sufficiently well developed or integrated with the subschema of intention for the person to understand herself and consequently to undertake adequate actions. For example, the person knows very well what she wants (clearly outlined intention), understands the obstacles (clearly outlined complications), but does not know how to overcome them (poorly developed conditions for the realisation of intention). Another possibility: the person knows what she wants (clearly outlined intention), but does not understand the obstacles well enough (poorly outlined complications), and so she does not know how to cope with them (poorly outlined conditions for the realisation of intention). In both above cases the person is sufficiently motivated to try to better understand the mechanisms which block the realisation of intention (e.g. the mechanisms of anxiety or depression) or to explore strategies for the desired change and to introduce them into her life. It is therefore likely that in the construction of a coherent, hope-inspiring and meaningful story of oneself as a protagonist, who effectively copes with the challenges of life (see: Bauer, McAdams, \& Sakaeda, 2005), the I-e type insight will be the most useful - although not as much with regard to its motivational function, as the cognitive 
one. In the narrative perspective insight is a tool "in the service" of the autonarrative motivation. It can also be said that an interest in achieving the $I$-e insight is a result of the narrative motivation (anchored in the content of the sub-schema of intention) to create a coherent story, whereas the presence of insight is an indicator of the process of constructing this story (see understanding of insight as an epiphenomenon: Grosse Holtforth et al., 2007).

In yet another case, the intention may be poorly crystallised and the incoherence of autonarration may concern mostly the elementary, sub-schematic level. A person with a poorly developed sub-schema of intention does not know "what he wants", and in extreme cases does not even know "who he is" or even "if he is at all" (see McWilliams, 1994). As a consequence the person may not only not have the "intentional" bases for constructing coherent narrations about important life issues at his disposal, but he may in general have trouble with narrative formulation of elementary events in his life. If we assume that the ability to narrate events is a prerequisite for experiencing emotions, especially the complex ones (Lazarus, 1991), we can speak of the difficulty in experiencing of oneself and of others. Thus, the person does not initiate appropriate actions because he experiences neither the motives nor the emotions associated with them, which direct towards these actions Trzebiński, 2002). It seems that to such patients the $E-i$ type insight may be more beneficial, since it is directed at experiencing the self and at "expanding" the sub-schema of intention. It is possible that both the "positive" insight (stemming from a corrective experience of the therapeutic relationship) as well as those insights which constitute a negative reinforcement (related to becoming aware of life losses) may be useful in this case. Interestingly, in the context of problems with experiencing one's self, even a "painful" insight of the $E$ - $i$ type can be highly rewarding. For example, experiencing one's previously ignored feeling of loneliness may be one of the few experiences, available at this stage in therapy, which provides the person with a sense of identity. It is also possible that some autodestructive behaviours may as well reflect the narrative motivation to construct a coherent story, although they are associated with its more fundamental level, that is, the attempt to achieve a sense of self. Thanks to the $E-i$ type insight patients with considerably fragmented autonarrative schemas can have a better "sense of self", can gradually clarify their desires (intentions) and in time can use them as a basis for building more complex autonarrations, which will give them better understanding of themselves. Nonetheless, the expansion of the narrative sub-schema of intention may occur without the presence of the $E-i$ insight. The fundamental sub-schemas of intention (identical to experience schemas), which are coded in procedural memory, may develop as a consequence of implicit learning of rules of experiencing within 
the supportive therapeutic relationship. In this case the $E-i$ insight may serve as an indicator of the process of expansion of the narrative sub-schema of intention.

\section{Summary}

The basis of our analysis was the question why some patients do not change their behaviour despite having achieved insight. To answer it, we began with an attempt to identify mechanisms associated with insight, which might be responsible for the change in the patient's behaviour. Thus, we distinguished two types of insight: "more intellectual than emotional" (I-e) and "more emotional than intellectual" $(E-i)$, and we subsequently explored how and under what circumstances each of them could lead to a behaviour change.

We have shown that the I-e type insight expands the understanding of the mechanisms underlying the problem and of possible solutions, as well as that it can be especially useful for those patients whose desire to introduce a constructive change into their lives is based on the goal-oriented (conscious, intentional) motivation. Thanks to the $I-e$ insight patients acquire adequate resources for implementing change, which makes them feel more competent and more ready to modify their behaviour. The I-e insight, often associated with positive emotions of moderate intensity, may also be treated as a learning experience, which in itself is rewarding and motivating towards change.

On the other hand, the specific characteristic of the $E-i$ type insight is its expansion of the impulsive-affective (unconscious, automated) motivation. This type of insight may be especially beneficial for patients with a conflicted or ambiguous motivation for introducing change into their lives. Thanks to the $E-i$ insight these patients can clarify their motivation and thus pursue the behaviour change in a more intentional and effective manner. The $E-i$ type insight, with a component of strong, negative emotions, acts as an aversive factor, which motivates the patients to review their previous life goals and to abandon those which may be maladaptive. The E-i type insight with a component of strong positive emotions acts as a corrective experience, motivating the patient to develop new, more adaptive goals.

Moreover, we also analysed the influence that other factors, such as therapeutic relationship, patient's actions and narrative motivation, may have on behaviour change. We have shown that the therapeutic relationship buffers the negative emotions associated with the $E-i$ type insight, and that it can also be a subject of insight as well as a "noninsight" (basing on modification of procedural memory) factor of behaviour change. What is more, the patient's actions may not only be a result of insight, but also a cause of it or a factor deepening and consolidating insight. It is also justified to treat the (auto) narrative motivation as a primary factor in the process of behaviour change, in which 
insight merely mediates or indicates this process. We have shown - which corresponds with our previous conclusions regarding the applications of both types of insights - that patients with smaller deficits in the ability to construct autonarrations (having crystallised intentions, but not the conditions for their realisation) may find the I-e insight more beneficial, while those with greater deficits (with no crystallised intentions) might gain more from the $E-i$ insight.

\section{Conclusion}

Basing on our above discussion we can conclude that insight does not always lead to behaviour change for one of at least three reasons. First, the type of insight may be inadequate to the type of the patient's motivation; second, other factors may not sufficiently support the process of insight; and third, insight may not in itself carry the potential for change (although it can be a result of a change or an indicator of another process, which in turn leads to change).

The I-e type of insight in the case of patients with impulsive-affective motivation prevailing over goal-oriented motivation, or with considerable deficits in autonarration, will most probably not lead to the necessary changes on the motivational level. On the other hand, the E-i type insight in the case of patients with goal-oriented motivation dominating over the impulsive-affective one, or with smaller deficits in autonarration, will most likely not lead to changes - also necessary ones - on the level of analysis and planning. It may also be assumed that some patients with major autonarrative deficits, and being at a certain stage in their therapy, might benefit more from the $E$ - $i$ type insight with a component of negative emotions (aversive insight), while others could gain more from the $E-i$ type insight with a component of positive emotions (corrective insight).

Change-facilitating insight may be prevented by a weak therapeutic relationship. On one hand it does not provide the patient with sufficient amount of safety and encouragement to explore emotionally difficult material or new solutions; on the other, it limits the opportunities for work on the corrective insight into the real relationship between the patient and the therapist, which carries great potential for change. Insight may also not imply change if its mental representation is not sufficiently "reinforced" by new actions of the patient, resulting from the insight.

Finally, it may turn out that insight might not lead to behaviour change because for some groups of patients it is not a key factor of change. According to Blatt (2004), some patients benefit more from a good quality therapeutic relationship than from developing the concept of self. They may "restructure" their autonarrations without the use of consciousness - in their implicit memory, and possibly to a larger degree on the fundamental 
level of the sense of self rather than of constructing the mental meaning of events. The occasional insight may in such cases indicate the ongoing process of change rather than initiate it.

The hypotheses about different motivational functions of the I-e and E-i type insights (including the "aversive" and the "corrective" insight), as well as about their distinctive usefulness in case of different groups of patients, require empirical verification. A first step towards it could be a construction of an insight scale with several dimensions (see Johansson et al., 2010), while further steps might include carrying out studies on the benefits of insight depending on its type and the type of patients. In the construction of the insight scale it might be worth to include dimensions allowing for determination of the type of insight, such as, for example: a) "novelty" of material vs. "novelty" of connections between elements of material; b) presence of associative vs. logical connections; c) emotional saturation; and d) positive vs. negative valence of the content of insight. Verification of the hypothesis according to which patients, depending on the depth and kind of autonarration deficits, benefit more from the $I-e$ or $E-i$ type of insight, requires the use of methods of structural analysis of narration (see e.g. Trzebiński, 2002). To estimate the autonarrative deficits it might be useful to analyse the patient's utterances regarding their "most important life issues" with regard to the degree of crystallisation of individual components of autonarration, including intentions, complications and conditions for realising the intentions.

Further, it will be worth examining which type of insight might be the most beneficial to the patients with differing degrees of personality organisation (Gabbard, 2010; McWilliams, 1994). In the context of the above discussion it can be assumed that the $I-e$ type insight might more often be beneficial to persons on the neurotic level of personality organisation, while the $E-i$ insight might be more useful to patients on the borderline level. This assumption corresponds to the results of several studies, which show better effects of transference interpretation (aimed at the $E$-i type insight) in patients with a low score on the scale of maturity of the object relation than in patients with a high score (Connolly et al., 1999; Høgland, 1993, Høgland et al., 2006, Johansson et al., 2010). Separate predictions need to be made regarding the aversive and corrective types of the $E-i$ insight. Most probably the aversive $E-i$ insight could prove harmful to patients on the psychotic level of personality organisation due to the risk of decompensation under the influence of strong negative emotions (Butzlaff \& Hooley, 1998; c.f. McWilliams, 1994). Thus, we can speculate that the aversive type of the $E-i$ insight may be more beneficial to the "healthier" patients with borderline organisation, while the corrective insight might be more useful to the borderline patients placing closer to the psychotic end of the spectrum. 
Finally, we would like to point out that the typology if insights, proposed as an attempt to answer the question in the title, appears to carry potential for explanation of mechanisms of therapeutic change in different groups of patients. However, it is at the moment exploratory in character. It is necessary to further develop it theoretically as well as confirm it through empirical studies.

\section{References:}

Ablon, J.S., \& Jones, E.E. (1999). Psychotherapy process in the National Institute of Mental Health Treatment of Depression Collaborative Research Program. Journal of Consulting and Clinical Psychology, 67, 1, 64-75.

Amini, F., Lewis, T., Lannon, R., Louie, A., Baumbacher, G., McGuinness, T., \& Schiff, E.Z. (1996). Affect, attachment, memory: contributions toward psychobiologic integration. Psychiatry, 59, 3, 213-239.

Angus, L, \& Bouffard, B. (2004). The search for emotional meaning and self-coherence in the face of traumatic loss in childhood: A narrative process perspective. In: J.D. Raskin (Ed.), Studies in meaning 2: Bridging the personal and social in costructivist psychology. New York: Pace University Press, 137-156.

Bargh, J.A. (1997). Automacity of everyday life. Advances in Social Cognition, 10, 1-61.

Barrett, L.F., Tugade, M., \& Engle, R. (2004). Individual differences in working memory capacity and dual-process theories of the mind. Psychological Bulletin, 130, 553-573.

Bauer, J.J., McAdams, D.P., \& Sakaeda, A.R. (2005). Crystallization of desire and crystallization of discontent in narratives of life-changing decisions. Journal of Personality, 73, 5, 1181-1214.

Blatt, S.J. (2004). Experiences of Depression. Washington, DC: American Psycholoogical Association.

Bruner, J.S. (1986). Actual Minds, possible worlds. Cambridge: Harvard University Press.

Butzlaff, R.L., \& Hooley, J.M. (1998). Expressed emotion and psychiatric relapse: a meta-analysis. Archives of General Psychiatry, 55, 547-552.

Cautela, J.R. (1993). Insight in behavior therapy. Journal of Behavior Therapy and Experimental Psychiatry, 24, 155-159.

Connolly Gibbons, M.B., Crits-Christoph, P., Barber, J.P., \& Schamberger, M. (2007). Insight in psychotherapy: A review of empirical literature. In: L. Castonguay, C. Hill (Eds.), Insight in psychotherapy. Washington, DC: American Psychological Association, 143-165. 
Connolly Gibbons, M.B., Crits-Christoph, P., Barber, J.P., Stirman, S.W., Gallop, W., Goldstein, L.A., \& Ring-Kurtz, S. (2009). Unique and common mechanisms of change across cognitive and dynamic psychotherapies. Journal of Consulting and Clinical Psychology, 77, 801-813.

Connolly, M.B., Crits-Christoph, P., Shappel, S., Barber, J.P., Luborsky, L., \& Shaffer, C. (1999). Relations of transference interpretations to outcome in the early sessions of brief supportive-expressive psychotherapy. Psychotherapy Research, 9, 485-495.

Cozolino, L.J. (2002). The neuroscience of psychotherapy. Building and rebuilding the human brain. New York: WW Norton \& Company.

DeShazer, S. (1985). Keys to solution in brief therapy. New York: WW Norton \& Company. Elliott, R., Shapiro, D.A., Firth-Cozens, J., Stiles, W.B, Hardy, G.E., Llewelyn, S.P., \& Margison, F.R. (1994). Comprehensive process analysis of insight events in cognitive-behavioral and psychodynamic-interpersonal psychotherapies. Journal of Counseling Psychology, 41, 449-463.

Epstein, S. (1991). Cognitive-experiential self-theory. In: L.A. Pervin (Ed.), Handbook of personality: Theory and research. New York: Guilford, 165-192.

Frank, J.D., \& Frank, J.B. (1993). Persuasion and healing: a comparative study of psychotherapy. Baltimore: Johns Hopkins University Press.

Franken, R.E. (2002). Human motivation. 5th Edition Belmont, CA: Wadsworth/Thomson Learning.

Friedman, R. (2011, January 17). When self-knowledge is only the begining. The New York Times. Retrieved from: http://www.nytimes.com/2011/01/18/health/views/18mind. html?_r=0.

Gabbard, G.O. (2010). Long-term psychodynamic psychotherapy: a basic text, Second Edition. Washington D.C. and London UK: American Psychiatric Publishing, Inc.

Gelso, C.J. (2002). Real relationship: The "something more" of psychotherapy. Journal of Contemporary Psychotherapy, 32, 35-40.

Gelso, C.J., \& Harbin, J. (2007). Insight, action, and the therapeutic relationship. In: L. Castonguay, \& C. Hill (Eds.), Insight in psychotherapy. Washington, DC: American Psychological Association, 293-311.

Gelso, C.J., Hill, C.E., Mohr, J.J., Rochlen, A.B., \& Zack, J. (1999). Describing the face of transference: Psychodynamic therapists' recollections about transference in cases of successful long-term therapy. Journal of Counseling Psychology, 46, 257-267. 
Greenberg, L.S. (2002). Emotion-focused therapy: Coaching clients to work though their feelings. Washington, DC: American Psychological Association.

Greenwald, H. (1973). Direct decision therapy. New York: Peter Vyden.

Grencavage, L.M., \& Norcross, J.C. (1990). Where are the commonalities among the therapeutic common factors? Professional Psychology: Research and Practice, 21, $5,327-378$.

Grosse Holfort, M., Castonguay, L.G., Boswell, J.F., Wilson, L.A., Kakouros, A.A., \& Borkovec, T.D. (2007). Insight in cognitive-behavioral therapy. In: L. Castonguay, \& C. Hill (Eds.), Insight in psychotherapy. Washington, DC: American Psychological Association, 57-80.

Harber, K.D., \& Pennebaker, J.W. (1992). Overcoming traumatic memories. In: S. Christianson (Ed.), The handbook of emotion and memory: Research and theory. Hillsdale: Lawrence Erlbaum, 359-387.

Hartman, D., \& Zimberoff, D. (2004). Corrective emotional experience in the therapeutic process. Journal of Heart-Centered Therapies, 7, 2, 3-84.

Hill, C.E, \& O’Brien, K.M. (1999). Helping skills: Facilitating, exploration, insight, and action. Washington, DC: American Psychological Association.

Hill, C.E., Castonguay, L.G., Angus, L., Arnkoff, D.B., Barber, J.P., Bohart, A.C.,..\& Wampold, B.E. (2007). Insight in psychotherapy: Definitions, processes, consequences, and research directions. In: L. Castonguay, \& C. Hill (Eds.), Insight in psychotherapy. Washington, DC: American Psychological Association, 441-454.

Høgland, P. (1993). Suitability for brief dynamic psychotherapy: Psychodynamic variables as predictors of outcome. Acta Psychiatrica Scandinavica, 88, 104-110.

Høgland, P., Amlo, S., Marble, A., Bøgwald, K-P., Sørbye, Ø, Sjaastad, M.C., \& Heyerdahl, O. (2006). Analysis of the patient-therapist relationship in dynamic psychotherapy: An experimental study of transference interpretations. American Journal of Psychiatry, 163, 1739-1746.

Høglend, P., Engelstad, V., Sørbye, Ø., Heyerdahl, O., \& Amlo, S. (1994). The role of insight in exploratory psychodynamic psychotherapy. British Journal of Medical Psychology, 67, 305-317.

Johansson. P., Høglend, P., Ulberg, R., Amlo, S., Marble, A., Bøgwald, K-P.,... \& Heyerdahl, O. (2010). The Mediating Role of Insight for Long-Term Improvements in Psychodynamic Therapy. Journal of Consulting and Clinical Psychology, 78, 3, 438-448. 
Jones, E.E., \& Pulos, S.M. (1993). Comparing the process in psychodynamic and cognitive-behavioral therapies. Journal of Consulting and Clinical Psychology, 61, 306316.

Kallestad, H. Valen, J. McCullough, L., Svartberg, M., Høglend, P., \& Stiles, T.H. (2010). The relationship between insight gained during therapy and long-term outcome in short-term dynamic psychotherapy and cognitive therapy for cluster $\mathrm{C}$ personality disorders. Psychotherapy Research, 20, 526-534.

Kottler, J.A. (1992). Compassionate Therapy. Working with difficult clients. San Francisco: Jossey-Bass Inc.

Kuncewicz, D. (2009). Co dzieje się z przeniesieniem po jego interpretacji? [What happens with transference after its interpretation?]. Przeglad Psychologiczny, 52, 3, 277-292.

Lazarus, A.A. (1991). A plague on Litttle Hans and Little Albert. Psychotherapy, 28, 444-447.

Lyons-Ruth, K. (1998). Members of the change process study group: Implicit relational knowing: its role in development and psychoanalytic treatment. Infant Mental Health Journal, 19, 282-289.

Mahoney, M.J., Norcross, J.C., Prochaska, J.O., \& Missar, C.D. (1989). Psychological development and optimal psychotherapy: converging perspectives among clinical psychologists. Journal of Integrative and Eclectic Psychotherapy, 8, 251-63.

McAdams, D.P., Diamond, A., de St. Aubin, E., \& Mansfield, E. (1997). Stories of commitment: The psychosocial construction of generative lives. Personality and Social Psychology, 72, 678-694.

McLeod J. (1997). Narrative and psychotherapy. London: Sage Publications.

McWilliams, N. (1994). Psychoanalytic Diagnosis. Understanding Personality Structure in the Clinical Process. New York: The Guilford Press.

Murray, S.L., Holmes, J.G., \& Collins, N.L. (2006). Optimizing assurance: The risk regulation system in relationships. Psychological Bulletin, 132, 641-666.

Niederhoffer, K.G., \& Pennebaker, J.W. (2002). Sharing one's story. On benefits of writing or talking about emotional experience. In: C.R. Snyder, \& S.J. Lopez (Eds.), Handbook of positive psychology. New York: Oxford University Press, 573-583.

Niedźwieńska, A. (2004). Poznawcze mechanizmy zniekształceń w pamięci zdarzeń. [Cognitive mechanisms of distortions in event memory] Kraków: WUJ. 
Powell, D.H. (1986). Spontaneous insights and the process of behavior therapy: Cases in support of integrative psychotherapy. Psychiatric Annals, 18, 288-295.

Powell, D.H. (1996). Behavior therapy-generated insight. In: J.R. Cautela, \& W. Ishaq (Eds.), Contemporary issues in behavior therapy: Improving the human condition. New York: Plenum Press, 301-314.

Rottenberg, J., \& Gross, J.J. (2007). Emotion and emotion regulation: A map for psychotherapy researchers. Clinical Psychology: Science and Practice, 14, 4, 323-328.

Rubinstein-Nabarro, N. (1996). Systemic insight in family therapy. Contemporary Family Therapy, 18, 1, 19-40.

Sandler, J., Dare, C., \& Holder, A. (1973). Interpretations, other interventions and insight. In: J. Sandler (Ed.), The patient and the analyst: The basis of the psychoanalytic process. New York, NY: Basic Books, 104-120.

Smith, E.R., \& DeCoster, J. (2000). Dual process models in social and cognitive psychology: Conceptual integration and links to underlying memory systems. Personality and Social Psychology Review, 4, 108-131.

Strack, F., \& Deutsch, R. (2004). Reflective and impulsive determinant of social behawior. Personality and Social Psychology Review, 8, 3, 220-247.

Tang, T.Z., \& DeRubeis, R.J. (1999). Sudden gains and critical sessions in cognitivebehavioral therapy for depression. Journal of Consulting and Clinical Psychology, 67, 894-904.

Trzebiński, J. (2002). Autonarracje nadają kształt życiu człowieka [Autonarrations shape human life]. In: J. Trzebiński (Ed.), Narracja jako sposób rozumienia świata [Narratives as the ways of world understanding]. Gdańsk: Gdańskie Wydawnictwo Psychologiczne, 43-80.

Wachtel, P.L. (1997). Psychoanalysis, behavior therapy, and the relational world. Washington, DC: American Psychological Association.

Yalom, I. D. (1980). Existential psychotherapy. New York: Basic Books.

Zeigarnik, B.W. (1927/1983). Podstawy psychopatologii klinicznej. [The basis of clinical psychopathology]. Warszawa: Państwowe Wydawnictwo Naukowe. 